\title{
콘크리트 $\mathrm{CO}_{2}$ 저감을 고려한 혼화재 및 단위 결합재 양의 설계
}

\author{
양근혁 ${ }^{1 *} \cdot$ 문재흠 ${ }^{2}$ \\ ${ }^{1)}$ 경기대학교 플랜트건축공학과 ${ }^{2)}$ 한국건설기술연구원 $\mathrm{SOC}$ 성능연구소 인프라구조연구실
}

\section{Design of Supplementary Cementitious Materials and Unit Content of Binder for Reducing $\mathrm{CO}_{2}$ Emission of Concrete}

\author{
Keun-Hyeok Yang ${ }^{1) *}$ and Jae-Heum Moon ${ }^{2)}$ \\ ${ }^{1)}$ Dept. of PlantArchitectural Engineering, Kyonggi University, Suwon 443-760, Korea \\ ${ }^{2)}$ SOC Research Institute, Korea Institute of Construction Technology, Goyang 411-712, Korea
}

\begin{abstract}
The present study assessed the $\mathrm{CO}_{2}$ emissions of concrete according to the type and replacement ratio of supplementary cementitious materials (SCM) and concrete compressive strength using a comprehensive database including 2464 cement concrete specimens and 776 cement concrete mixes with different SCMs. The system studied in $\mathrm{CO}_{2}$ assessment of concrete based on Korean lifecycle inventory was from cradle to pre-construction, which includes consistent materials, transportation and production phases. As the performance efficiency indicators, binder and $\mathrm{CO}_{2}$ intensities were analyzed, and simple equations to evaluate the amount of $\mathrm{CO}_{2}$ emission of concrete were then formulated as a function of concrete compressive strength and the replacement ratio of each SCM. Hence, the proposed equations are expected to be practical and useful as a guideline to determine the type and replacement ratio of SCM and unit content of binder in concrete mix design that can satisfy the target compressive strength and $\mathrm{CO}_{2}$ reduction percentage relative to cement concrete.
\end{abstract}

Keywords : $\mathrm{CO}_{2}, \mathrm{SCM}$, unit content of binder, compressive strength

\section{1. 서 론}

건설산업에서 가장 많이 이용되는 콘크리트의 핵심성 분을 다루는 시멘트 산업은 국가 기간산업 중의 하나이 다. 우리나라는 1919년도에 시멘트 공장의 설립과 함께 1970년대 이후 확장기를 거쳐 1990년대 후반에는 세계 5위권에 달하는 시멘트 생산국으로 도약하였다. ${ }^{1)}$ 1998년 도에는 년간 6000 만 톤을 초과하는 생산능력을 보유하 면서 2000년도 이후 연간 평균 시멘트 소비량은 5000 만 톤에 달하고 있다. 이에 따라 국내 시멘트 산업은 이전 의 성장기반을 발판으로 성숙기에 접어들었다고 평가되 고 있다. 하지만 시멘트 산업은 온실가스를 포함한 환경 영향 저감에 대한 강력한 정책적·사회적 요구의 증가 와 함께 2000년도 이후 지속가능성을 기반으로 하는 중 장기적 대책을 필요로 하고 있다.

시멘트 제조 시 발생하는 $\mathrm{CO}_{2}$ 양은 우리나라 전체 $\mathrm{CO}_{2}$

${ }^{*}$ Corresponding author E-mail : yangkh@kyonggi.ac.kr

Received May 15, 2012, Revised June 25, 2012,

Accepted July 5, 2012

(c) 2012 by Korea Concrete Institute
배출량의 약 $6.5 \%$ 에 해당하며, 콘크리트 제조 및 타설까 지의 $\mathrm{CO}_{2}$ 발생량을 고려하면 그 비율은 약 $10 \%$ 까지 증 가한다. ${ }^{2)}$ 또한 일반적으로 시멘트 산업에서 배출되는 $\mathrm{CO}_{2}$ 양은 전세계 배출량의 약 $7 \%$ 로 평가되고 있다.") 시멘트 를 제조할 때 배출되는 $\mathrm{CO}_{2}$ 배출은 일반적으로 석회석 의 탈탄산 과정, 화석연료 연소, 분쇄 시 소모되는 전력 및 발전기 가동을 위한 기름 연소 등에 기인한다. 석회석 의 탈탄산 과정에서 발생되는 $\mathrm{CO}_{2}$ 는 시멘트 제조 시 배 출량의 약 $59 \%$ 를 차지하며, 석회석의 소성 시 화석연료 연소로 인한 $\mathrm{CO}_{2}$ 발생양은 약 $31 \%$ 를 차지한다. 이는 시 멘트 산업이 막대한 에너지원을 필요로 함을 또한 의미 한다. 에너지 소비 절감과 온실가스 감축이라는 전 세계 적 화두 앞에서 시멘트 및 콘크리트 산업에서의 환경영 향 개선은 우리나라 녹색성장을 위해서도 필연이다. 특 히 우리나라의 전과정 평가(life cycle assessment, LCA) 에 의한 보통 포틀랜드 시멘트(ordinary portland cement, $\mathrm{OPC}$ )의 $\mathrm{CO}_{2}$ 배출계수는 $0.931 \mathrm{CO}_{2}-\mathrm{kg} / \mathrm{kg}$ 으로서, 세계 평 균인 $0.81 \mathrm{CO}_{2}-\mathrm{kg} / \mathrm{kg}$ 비해 약 1.15 배 높다. 따라서 콘크리 트 산업에서 $\mathrm{CO}_{2}$ 절감대책은 매우 중요한 이슈임이 분 명하다. 
시멘트 산업에서 $\mathrm{CO}_{2}$ 저감을 위한 노력으로는 에너지 효율설비 확충, 대체연료 사용증대, 석회석과 같은 시멘 트 혼합재의 비율증가, 에너지 저소비형 클링커 제조 및 고로슬래그와 같은 혼화재(supplementary cementitious material, $\mathrm{SCM}$ )들의 첨가 등을 들 수 있다. ${ }^{4)}$ 이들 노력 중 고로슬래그(ground granulated blast-furnace slag, GGBS) 나 플라이애쉬(fly ash, FA)와 같은 산업부산물을 활용한 혼합시멘트의 사용은 일반적으로 현장에서 쉽게 접근할 수 있는 방법이다. 더구나 GGBS나 $\mathrm{FA}$ 의 사용은 천연자 원 보존 및 산업부산물의 재활용이라는 부가적인 효과도 기대할 수 있다. 따라서 산업부산물을 이용한 혼화재의 첨가가 $\mathrm{OPC}$ 콘크리트에서의 $\mathrm{CO}_{2}$ 배출량 저감에 미치는 영향을 정량적으로 쉽게 평가할 수 있는 기술의 마련은 환경배려형 콘크리트 배합을 위해 매우 중요하게 고려될 사항이다. 이는 또한 콘크리트 배합에서 $\mathrm{CO}_{2}$ 저감을 위 한 혼화재를 포함한 결합재의 설계 및 단위 결합재 양 을 결정하는데 중요하게 이용될 수 있다.

이 연구의 목적은 콘크리트 배합에서 $\mathrm{CO}_{2}$ 배출량을 비 교적 쉽게 예측하고, 이를 바탕으로 목표 압축강도와 $\mathrm{CO}_{2}$ 배출 저감양에 대한 혼화재의 첨가 및 단위 결합재 양을 결정할 수 있는 방법을 제시하는 것이다. 콘크리트 $\mathrm{CO}_{2}$ 배출량의 평가는 국가 전과정 목록(life cycle inventory, $\mathrm{LCI}$ 데이터베이스이에 기반하여 각 구성재료의 생산과 레 미콘 공장까지의 운송, 그리고 콘크리트의 생산과 현장까 지의 운송 등을 고려하였다. 결합재의 환경영향을 분석하 기 위한 지표로서 Damineli 등에 에 의해 제시된 콘크리트 단위 압축강도 $(1 \mathrm{MPa})$ 발현을 위한 결합재 양과 그때의 $\mathrm{CO}_{2}$ 배출량을 나타내는 결합재 지수 및 $\mathrm{CO}_{2}$ 지수를 이 용하였다. 궁극적으로 결합재 지수와 $\mathrm{CO}_{2}$ 지수의 상관관 계 모델에서 혼화재의 종류와 치환율의 영향을 고려함으 로서 혼합 시멘트 콘크리트의 $\mathrm{CO}_{2}$ 저감률을 확인하였다.

\section{2. $\mathrm{CO}_{2}$ 평가 절차}

전과정 평가는 크게 3 단계로 구분된다. ${ }^{7}$ 첫 번째 단계 에서 기능 단위와 시스템 경계가 정의된다. 두 번째 단 계에서는 에너지의 정의와 사용량, 재료 소비 및 폐기물 양과 $\mathrm{CO}_{2}$ 배출량 등을 포함하는 원단위 데이터가 구축 되고, 세 번째 단계에서는 이들 데이터를 이용하여 요구 조건에 대한 환경영향을 평가한다.

\section{1 기능단위 및 시스템 경계}

콘크리트 구조물의 전과정 평가 시스템은 Fig. 1에 나 타낸 바와 같이 구성재료들의 생산 및 운반, 콘크리트 생산 및 운반, 구조물의 시공, 사용연한 및 폐기 등으로 구성될 수 있다. ${ }^{8}$ 따라서 전과정 평가에 의한 콘크리트 의 $\mathrm{CO}_{2}$ 배출량은 Fig. 1 에 나타낸 모든 요소들을 고려해 야 하지만 콘크리트의 타설, 사용연한 및 폐기의 과정에 서 배출되는 $\mathrm{CO}_{2}$ 양에 대한 원단위의 평가는 구조물의

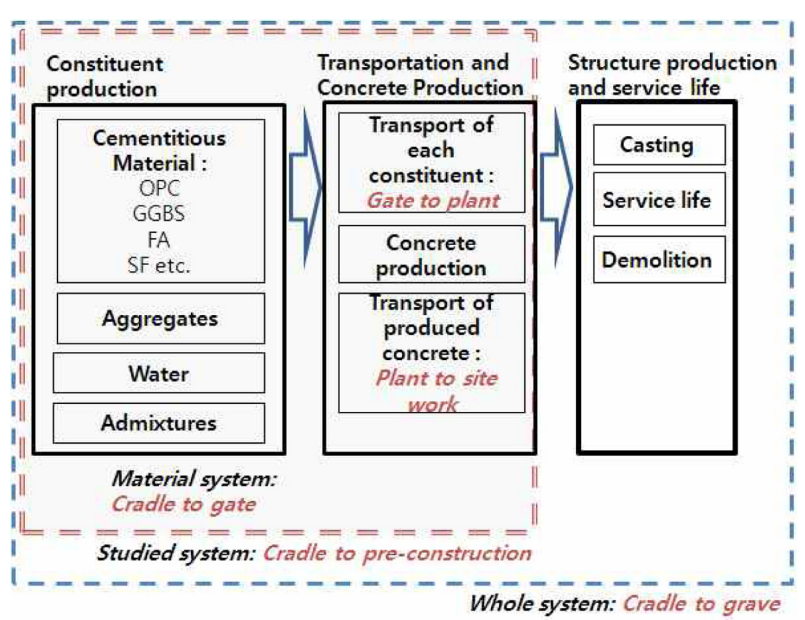

Fig. 1 Schematic identification of concrete lifecycle

기능 및 규모에 따라 달라지므로 이에 대한 데이터의 구 축은 매우 어렵다. 또한 콘크리트 구조물의 사용연한 동 안 탄산화를 통해 흡수되는 $\mathrm{CO}_{2}$ 양도 고려될 필요가 있 지만 공기에 노출된 콘크리트 면적 및 $\mathrm{CO}_{2}$ 농도 등의 평가가 필요하므로 무시하였다. 즉 이 연구에서 고려된 시스템은 요람에서부터 현장에서의 타설 직전까지의 단 계로서 구성재료, 운반, 콘크리트 생산 등에서 배출되는 $\mathrm{CO}_{2}$ 양을 포함하였다. 이 연구에서 고려된 시스템은 구 조물의 사용연한을 고려하지 않기 때문에 내구성도 포함 하지 않는다. 더구나 콘크리트는 일반적으로 $1 \mathrm{~m}^{3}$ 단위 로 주문과 생산이 이루어진다. 따라서 이 $\mathrm{CO}_{2}$ 평가에서 고려된 콘크리트의 기능단위는 $1 \mathrm{~m}^{3}$ 이다.

콘크리트의 기능단위에 대한 각 재료의 출구에서부터 콘크리트 시공 전 단계까지의 시스템에서 배출된 전체 $\mathrm{CO}_{2}$ 양 $\left(C_{d}\right)$ 은 다음에 의해 산정될 수 있다.

$$
C_{d}=\mathrm{CO}_{2-M}+\mathrm{CO}_{2-T}+\mathrm{CO}_{2-P}
$$

여기서, $\mathrm{CO}_{2-M}$ 은 시멘트, 각 혼화재, 골재, 물 및 혼화제 (감수제)를 포함하는 재료단계에서의 $\mathrm{CO}_{2}$ 배출량이며, $\mathrm{CO}_{2-T}$ 는 각 재료 및 생산된 콘크리트의 운반단계에서의 $\mathrm{CO}_{2}$ 배출량이며, $\mathrm{CO}_{2-P}$ 는 공장에서 콘크리트 배합을 위 해 소비되는 전력으로부터 산정된 생산단계에서의 $\mathrm{CO}_{2}$ 배출량이다. 재료단계인 $\mathrm{CO}_{2-M}$ 은 다음 식에 의해 산정된다.

$$
C O_{2-M}=\sum_{i=1}^{n}\left(W_{i} \times C O_{2(i)-L C I}\right)
$$

여기서, $i$ 는 콘크리트 생산을 위해 이용된 각 재료들이며, $n$ 은 이들 재료들의 수이며, $W_{i}$ 와 $\mathrm{CO}_{2(i)-L C I}$ 는 각각 재료 $i$ 의 단위질량 $\left(\mathrm{kg} / \mathrm{m}^{3}\right)$ 과 $\mathrm{CO}_{2}$ 배출계수 $\left(\mathrm{CO}_{2}-\mathrm{kg} / \mathrm{kg}\right)$ 이다. 운반 단계에서의 $\mathrm{CO}_{2}$ 배출량인 $\mathrm{CO}_{2-T}$ 는 다음과 같이 산정된다.

$$
\begin{aligned}
C O_{2-T}= & \sum_{i=1}^{n}\left(W_{i} \times D_{i} \times C O_{2(i)-L C I(T R)}\right) \\
& +D_{B} \times C O_{2-L C I(T R-c o n)}
\end{aligned}
$$


여기서, $D_{i}$ 는 재료 $i$ 의 출구에서 레미콘 공장까지의 운반 거리 $(\mathrm{km})$ 이며, $\mathrm{CO}_{2(i)-L C I(T R)}$ 은 운반수단의 $\mathrm{CO}_{2}$ 배출계수 $\left(\mathrm{CO}_{2}-\mathrm{kg} / \mathrm{km} \cdot \mathrm{kg}\right)$ 이며, $D_{B}$ 는 콘크리트의 공장에서 현장까지 의 운반거리 $(\mathrm{km})$ 이며, $\mathrm{CO}_{2(i)-L C I(T R-c o n)}$ 은 레미콘 차량의 $\mathrm{CO}_{2}$ 배출계수 $\left(\mathrm{CO}_{2}-\mathrm{kg} / \mathrm{km} \cdot \mathrm{kg}\right)$ 이다. 운반단계에서의 $\mathrm{CO}_{2}$ 배 출량을 산정하기 위하여 레미콘 공장의 위치는 서울 방 배동으로 가정하였다. 시멘트는 전남 담양, 굵은골재와 잔 골재는 경기도 광주와 인천, $\mathrm{FA}$ 는 경남 하동, GGBS는 전 남 광양, 실리카 품(silica fume, $\mathrm{SF}$ )은 인천, 혼화제는 평 택에서 운송됨을 가정하였다. 물은 상수도를 통해 조달되 므로 운송수단을 통한 평가는 무시하였다.

\section{$2.2 \mathrm{LCl}$ 데이터베이스}

LCI 데이터는 기온, 에너지원 및 천연자원의 차이에 따라 각 나라에 따라 상이하므로, 자국에서 제공되는 원 단위를 이용하는 것이 가장 바람직하다. 우리나라는 국 토해양부, 환경부와 지식경제부에서 물질 및 부품제조, 가공공정, 수송, 사용 및 폐기활동 등에 대하여 약 400 여개의 LCI 데이터베이스를 구축하고 있다. 이 중 건설 활동에 관련된 데이터는 약 60 여 개로서 일본(약 130 여 개) 등의 선진국에 비해 적은 상황이다. 이 연구에서 고 려된 Fig. 1의 시스템에서 각 재료 및 운반에 대한 LCI 는 기본적으로 국내 데이터 ${ }^{5)}$ 를 이용하였다. 콘크리트 생 산단계에서의 $\mathrm{CO}_{2}$ 배출량인 $\mathrm{CO}_{2-P}$ 는 플랜트 가동을 위 해 소비되는 전력, 유류, 가스 양 등으로부터 평가될 수 있으며, 계절에 따라 다소 변동이 있다. 콘크리트 플랜트 의 $\mathrm{CO}_{2}$ 배출계수에 대한 국내 LCI 데이터베이스는 아직 마련되지 않았기 때문에 이 연구에서는 일본토목학회9 에서 제시하는 데이터목록을 이용하였다. 재료 중에서도 $\mathrm{FA}$ 와 $\mathrm{GGBS}$ 는 일본토목학회 ${ }^{9}$ 의 자료를 이용하였으며, $\mathrm{SF}$ 는 $\mathrm{CEN}^{10)}$ 자료를 이용하였다.

\section{3 콘크리트 배합에 대한 데이터베이스}

혼화재가 콘크리트의 $\mathrm{CO}_{2}$ 배출량에 미치는 영향을 평 가하기 위하여 국내 논문집(대한건축학회, 한국콘크리트 학회 및 한국건축시공학회 등) 및 레미콘 사를 중심으로 콘크리트 배합 및 28 일 압축강도에 대한 데이터베이스를 구축하였다. 실험 데이터베이스는 모두 3240 개의 배합을 포함하고 있는데, 이 중 결합재로서 $\mathrm{OPC}$ 는 2464 배합, $\mathrm{OPC}+\mathrm{FA}$ 는 481 배합, $\mathrm{OPC}+\mathrm{GGBS}$ 는 92 배합, $\mathrm{OPC}+\mathrm{FA}+$ $\mathrm{GGBS}$ 는 23 배합, $\mathrm{OPC}+\mathrm{SF}$ 는 131 배합, $\mathrm{OPC}+\mathrm{FA}+\mathrm{SF}$ 는 46 배합, 기타 3 배합이다(Fig. 2). 재령 28일 압축강도의 범위는 $\mathrm{OPC}$ 콘크리트의 경우 $7.7 \sim 147 \mathrm{MPa}$ 이며, $\mathrm{OPC}+$ $\mathrm{SCM}$ 콘크리트의 경우에는 $13.3 \sim 125 \mathrm{MPa}$ 이다. 물-결합재 의 범위는 $\mathrm{OPC}$ 콘크리트의 경우 $15 \sim 88 \%$ 이며, $\mathrm{OPC}+$ $\mathrm{SCM}$ 콘크리트의 경우에는 $15 \sim 63 \%$ 이다. 단위 결합재 양 의 범위는 $\mathrm{OPC}$ 콘크리트의 경우 $150 \sim 1067 \mathrm{~kg} / \mathrm{m}^{3}$ 이며, $\mathrm{OPC}+\mathrm{SCM}$ 콘크리트의 경우에는 $234 \sim 1067 \mathrm{~kg} / \mathrm{m}^{3}$ 이다. 플

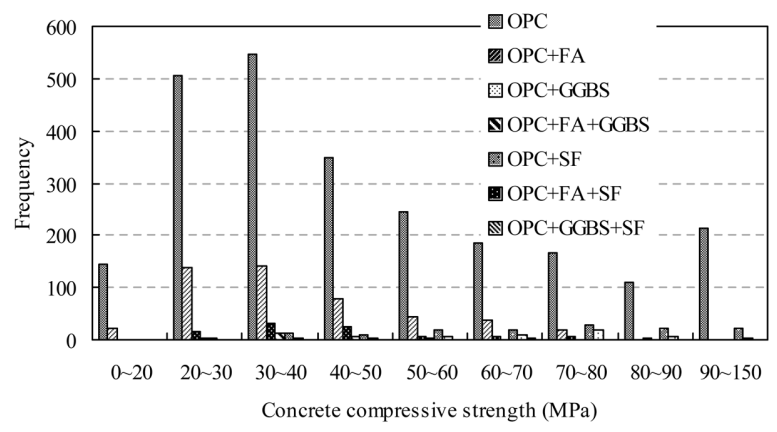

(a) Concrete compressive strength at 28 days

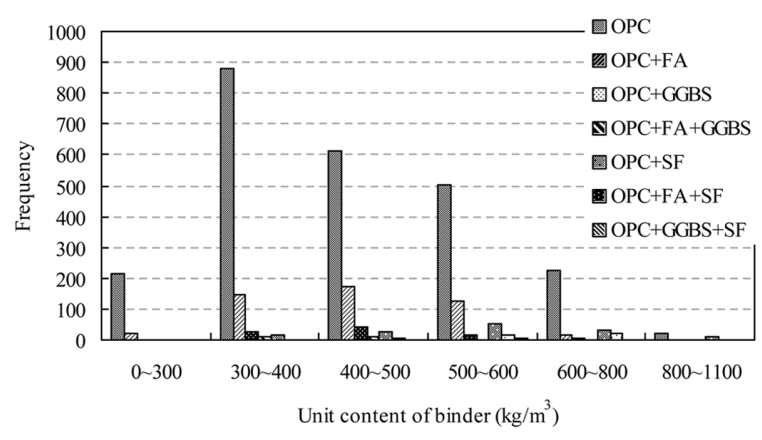

(b) Unit content of binder

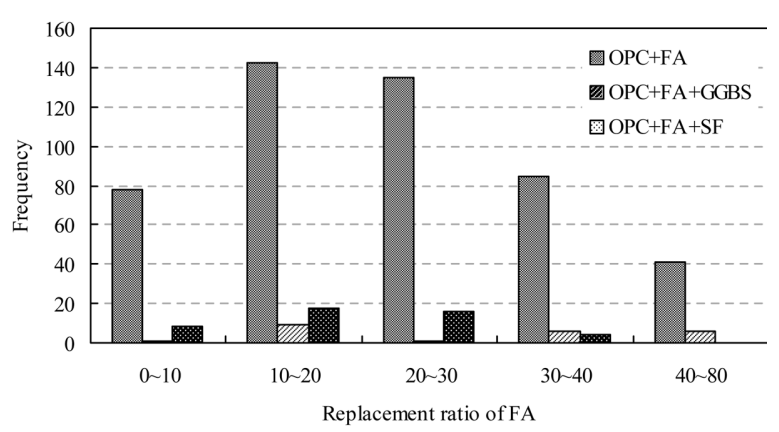

(c) Replacement ratio of FA

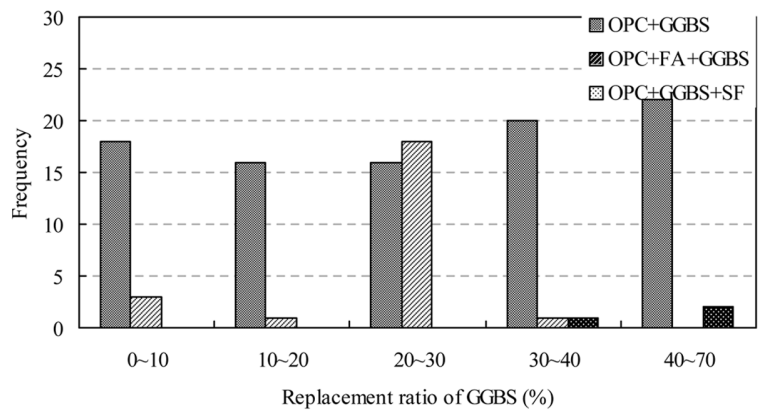

(d) Replacement ratio of GGBS

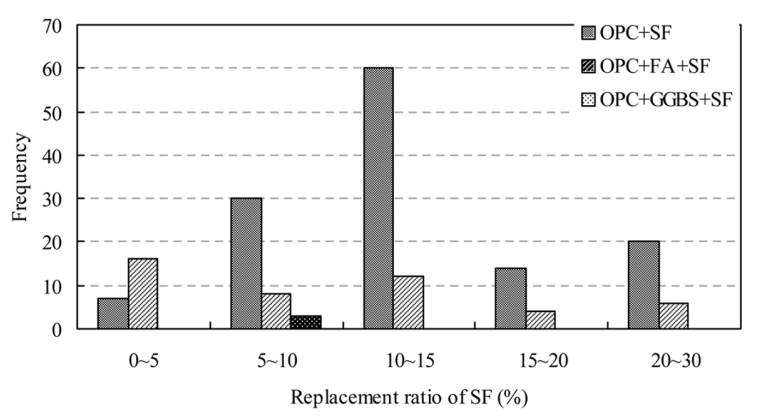

(e) Replacement ratio of SF

Fig. 2 Distribution of main parameters in the database 
라이애쉬, 고로슬래그, 실리카퓸의 최대 치환율은 각각 $70 \%, 69 \%$ 및 $30 \%$ 이었다.

\section{$2.4 \mathrm{CO}_{2}$ 평가 예}

압축강도 $\left(f_{c k}\right)$ 가 $40 \mathrm{MPa}$ 일 때 $\mathrm{FA}$ 와 $\mathrm{GGBS}$ 가 치환된 $\mathrm{OPC}$ 콘크리트에서 $\mathrm{CO}_{2}$ 평가 예를 Table 1에 나타내었 다. 콘크리트 기능단위는 $1 \mathrm{~m}^{3}$ 이다. Table에서 A열은 콘 크리트 배합에 관련된 정보로서 각 재료 및 콘크리트의 단위질량이며, $\mathrm{D}$ 열은 각 재료 및 콘크리트의 운반거리이 다. $\mathrm{A}$ 열에 각 재료 및 콘크리트 플랜트에서의 $\mathrm{CO}_{2}$ 배출 계수인 $\mathrm{B}$ 열을 곱하면 재료 및 생산단계에서의 $\mathrm{CO}_{2}$ 배 출량을 얻을 수 있다. 한편, 운반단계에서의 $\mathrm{CO}_{2}$ 배출량 은 식 (3)에 따라 $\mathrm{A}$ 열, $\mathrm{D}$ 열 및 $\mathrm{E}$ 열을 곱하면 얻을 수 있 다. 따라서 Table 1로부터 콘크리트 기능단위에 대한 재 료, 생산 및 운반단계에서 배출된 $\mathrm{CO}_{2}$ 양은 $402.09 \mathrm{~kg}$ 이 며, 이 중 $\mathrm{OPC}$ 에 의한 $\mathrm{CO}_{2}$ 양은 $336.1 \mathrm{~kg}$ 이다. 즉, $\mathrm{OPC}$ 재료에 의한 $\mathrm{CO}_{2}$ 배출량은 전체 배출량의 약 $83.6 \%$ 이 다. 한편, 운반과정에서 배출된 $\mathrm{CO}_{2}$ 양은 $31.57 \mathrm{~kg}$ 으로서 전체 배출량의 $7.8 \%$ 이다.

\section{3. 콘크리트 $\mathrm{CO}_{2}$ 양에 대한 결합재 영향}

Table 1에서 나타낸 바와 같이 $\mathrm{OPC}$ 재료에 의한 $\mathrm{CO}_{2}$ 배출량은 콘크리트 전체 배출량에서 가장 큰 비율을 차 지하므로 $\mathrm{OPC}$ 가 최소 사용된 결합재의 설계는 환경영
향의 최소 측면에서 매우 중요하다. 이에 따라 Damineli 등 ${ }^{6}$ 은 콘크리트의 환경에 대한 효율성은 소요 압축강도 및 내구연한에 대한 전체 결합재 소비측면에서 정의될 필 요가 있음을 제시하였다. 일반적으로 콘크리트는 물-결 합재비가 감소함에 따라 압축강도가 증가하므로, 높은 압 축강도 발현을 위해서는 많은 양의 결합재가 소비된다. 한편, 콘크리트의 압축강도 증가는 구조부재의 단면크기 를 줄일 수 있으므로 콘크리트 양의 감소에 의한 $\mathrm{CO}_{2}$ 저감효과를 기대할 수 있다. 따라서 단위 압축강도 $(1 \mathrm{MPa})$ 의 발현을 위한 결합재 양 및 이에 따른 $\mathrm{CO}_{2}$ 양이 평가 될 필요가 있다. 이 연구에서는 Damineli 등이이 제시한 결합재 지수 $\left(B_{i}\right)$ 와 $\mathrm{CO}_{2}$ 지수 $\left(C_{i}\right)$ 를 이용하여 결합재의 환 경성능을 평가하였다.

$$
\begin{aligned}
& B_{i}=B / f_{c k} \\
& C_{i}=C_{d} / f_{c k}
\end{aligned}
$$

여기서 $B$ 는 콘크리트 기능단위에 대한 결합재 양 $\left(\mathrm{kg} / \mathrm{m}^{3}\right)$ 이다.

\section{1 결합재 지수 $\left(B_{i}\right)$}

콘크리트의 압축강도 $\left(f_{c k}\right)$ 에 따른 결합재 지수 $\left(B_{i}\right)$ 를 Fig. 3에 나타내었다. 그림에서 데이터 수가 너무 많아 각 결 합재의 구별이 쉽지 않으므로 회귀분석으로부터 얻은 추

\begin{tabular}{|c|c|c|c|c|c|c|}
\hline \multirow{2}{*}{$\begin{array}{c}\text { Functional unit } \\
(\mathrm{FU}): \mathrm{m}^{3}\end{array}$} & \multicolumn{3}{|c|}{ Material } & \multicolumn{3}{|c|}{ Transportation } \\
\hline & A & $\mathrm{B}$ & $A \cdot B$ & $\mathrm{D}$ & $\mathrm{E}$ & $A \cdot D \cdot E$ \\
\hline Item & $\frac{\mathrm{kg}}{\mathrm{FU}}$ & $\frac{\mathrm{CO}_{2}-\mathrm{kg}}{\mathrm{kg}}$ & $\frac{\mathrm{CO}_{2}-\mathrm{kg}}{\mathrm{FU}}$ & $\mathrm{km}$ & $\frac{\mathrm{CO}_{2}-\mathrm{kg}}{\mathrm{kg} \cdot \mathrm{km}}$ & $\frac{\mathrm{CO}_{2}-\mathrm{kg}}{\mathrm{FU}}$ \\
\hline $\mathrm{OPC}^{(1)}$ & 361 & 0.931 & 336.1 & 277 & $5.1810^{-5}$ & 5.18 \\
\hline $\mathrm{GGBS}^{(1)}$ & 68 & $0.0265^{3)}$ & 1.802 & 339 & $5.1810^{-5}$ & 1.19 \\
\hline $\mathrm{FA}^{1)}$ & 23 & $0.0196^{3)}$ & 0.451 & 322 & $5.1810^{-5}$ & 0.38 \\
\hline Sand $^{(1)}$ & 805 & 0.0026 & 2.093 & 47 & $6.310^{-5}$ & 2.38 \\
\hline Coarse $^{(1)}$ & 918 & 0.0075 & 6.885 & 37.6 & $6.310^{-5}$ & 2.17 \\
\hline Water $^{(2)}$ & 163 & $1.9610^{-4}$ & 0.032 & - & - & - \\
\hline \multirow[t]{2}{*}{ Admixture } & 3.1 & $0.25^{3)}$ & 0.775 & 70.6 & $2.2110^{-4}$ & 0.05 \\
\hline & \multicolumn{2}{|c|}{ Sum } & 351.94 & \multicolumn{3}{|c|}{ - } \\
\hline \multirow[t]{2}{*}{ Concrete production ${ }^{4)}$} & \multirow[t]{2}{*}{2341} & \multirow[t]{2}{*}{0.00768} & \multirow[t]{2}{*}{17.98} & 30 & $\begin{array}{c}0.674 \\
\mathrm{CO}_{2}-\mathrm{kg} \\
\mathrm{m}^{3} \cdot \mathrm{km}\end{array}$ & $\mathrm{D} \cdot \mathrm{E}=20.22$ \\
\hline & & & & \multicolumn{2}{|c|}{ Sum } & 31.57 \\
\hline
\end{tabular}

Table 1 Example for $\mathrm{CO}_{2}$ assessment of concrete $\left(f_{c k}=40 \mathrm{MPa}\right)$

Total $=402.09 \mathrm{CO}_{2}-\mathrm{kg} / \mathrm{FU}\left(=351.94+17.98+31.57 \mathrm{CO}_{2}-\mathrm{kg}\right)$

1) All of the cementitious materials are assumed to be transported by a 23 ton capacity hydraulic truck, while aggregates are transported by a 15 ton capacity dump truck.

2) Water drawn from Han-river is used for concrete mix.

3) LCI data given in JSCE are referenced wherever Korean LCI database is unavailable.

4) The fresh concrete produced from the plant is transported to a building site by a $6 \mathrm{~m}^{3}$ capacity transit-mix truck. 


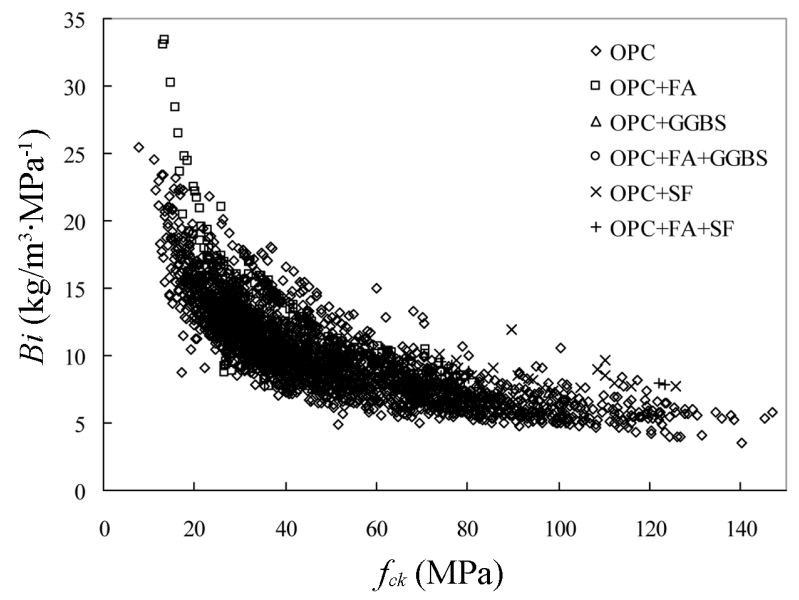

Fig. $3 f_{c k}$ versus $B_{i}$

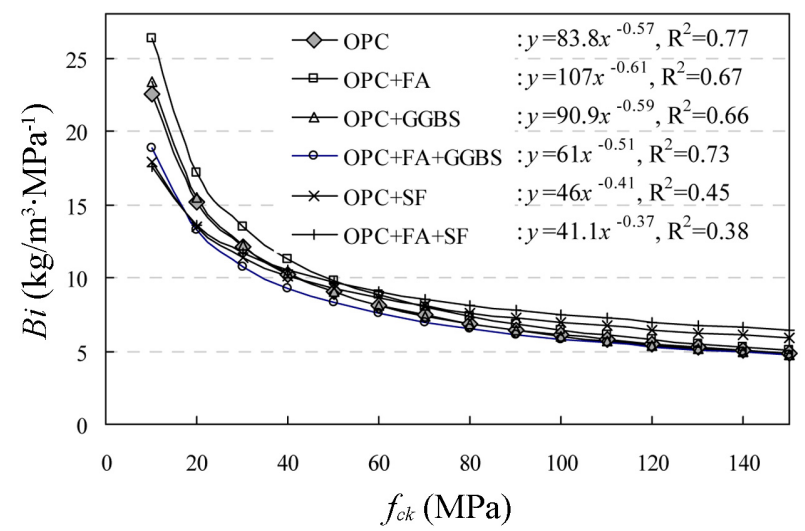

Fig. 4 Best-fit curves determined from $B_{i}$ data of Fig. 2

세선을 Fig. 4에 나타내었다. 실리카 품이 치환된 콘크리 트의 실험 데이터 수가 많지 않아 추세선의 상관계수 $\left(R^{2}\right)$ 값이 낮게 나타났다. 결합재 지수는 혼화재의 치환에 관 계없이 $f_{c k}$ 의 증가와 함께 감소하였다. 이는 압축강도가 증가함에 따라 단위 압축강도 $(1 \mathrm{MPa})$ 발현을 위한 결합 재 양이 감소됨을 의미한다. 결합재 지수의 감소속도는 $f_{c k}$ 가 약 $60 \mathrm{MPa}$ 이상에서 점차 완화되면서 혼화재 치환 에 관계없이 $B_{i}$ 의 값은 $5 \mathrm{~kg} / \mathrm{m}^{3} \cdot \mathrm{MPa}^{-1}$ 에 수렴하는 경향을 보였다. 고로슬래그가 치환된 콘크리트의 $B_{i}$ 값은 혼화재 가 치환되지 않은 $\mathrm{OPC}$ 콘크리트와 매우 비슷한 값을 보 였다. 실리카 품이 치환된 콘크리트의 $B_{i}$ 값은 $f_{c k}$ 가 약 40 $\mathrm{MPa}$ 이하에서 $\mathrm{OPC}$ 콘크리트보다 낮게 있었다. 반면 플 라이애쉬가 치환된 콘크리트의 $B_{i}$ 값은 동일 압축강도의 $\mathrm{OPC}$ 콘크리트보다 다소 높았는데, 이는 $\mathrm{FA}$ 가 치환된 콘 크리트에서는 결합재 양이 $\mathrm{OPC}$ 콘크리트보다 다소 증 가하고 있음을 의미한다.

\section{$3.2 \mathrm{CO}_{2}$ 지수 $\left(C_{i}\right)$}

콘크리트의 압축강도 $\left(f_{c k}\right)$ 에 따른 $\mathrm{CO}_{2}$ 지수 $\left(C_{i}\right)$ 를 Fig. 5 에 나타내었으며, 회귀분석으로부터 얻은 추세선의 비교 는 Fig. 6 에 나타내었다. 콘크리트의 $C_{i}$ 값은 $B_{i}$ 에서와 같

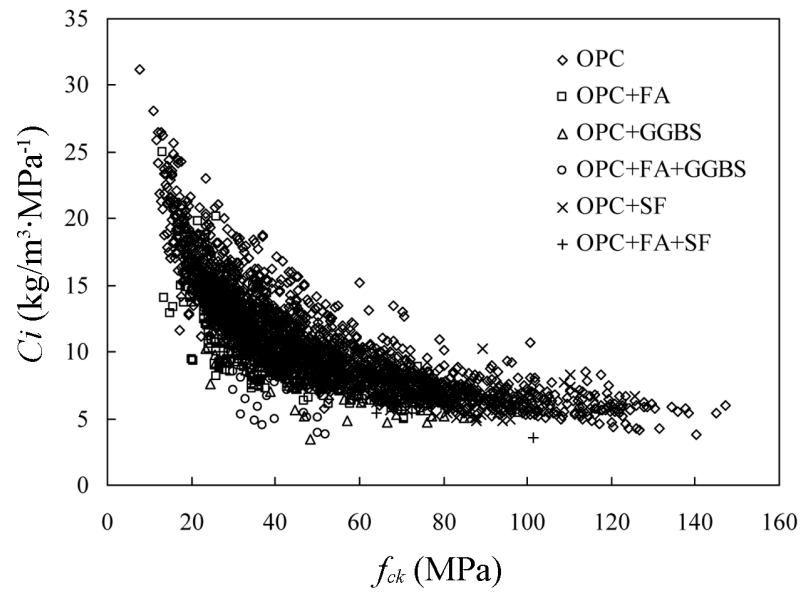

Fig. $5 f_{c k}$ versus $C_{i}$

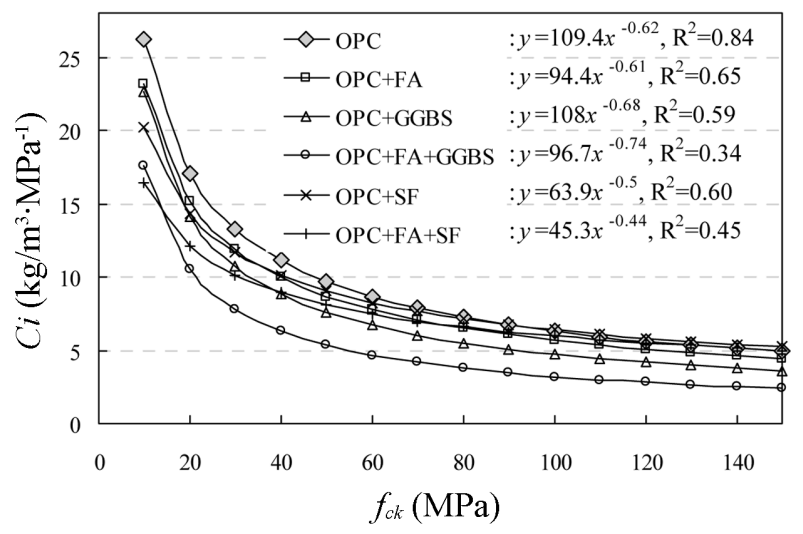

Fig. 6 Best-fit curves determined from $C_{i}$ data of Fig. 5

이 혼화재 치환에 관계없이 $f_{c k}$ 가 증가함에 따라 감소하 였다. 감소기울기는 $f_{c k}$ 가 $60 \mathrm{MPa}$ 이상에서 다소 완만하 였으며 $\mathrm{OPC}$ 콘크리트의 경우 약 $5 \mathrm{~kg} / \mathrm{m}^{3} \cdot \mathrm{MPa}^{-1}$ 에 수렴하 였다. 동일 $f_{c k}$ 에서는 $\mathrm{OPC}$ 의 $C_{i}$ 값이 가장 높았으며, 플라 이애쉬와 고로슬래그가 치환된 콘크리트의 $C_{i}$ 값이 가장 낮았다. 이는 콘크리트 단위 압축강도 $(1 \mathrm{MPa})$ 를 발현시킬 때 배출되는 $\mathrm{CO}_{2}$ 양은 $\mathrm{OPC}+\mathrm{FA}+\mathrm{GGBS}$ 결합재가 가장 작 게 있음을 의미한다. $\mathrm{OPC}+\mathrm{FA}+\mathrm{GGBS}$ 콘크리트의 $C_{i}$ 값은 $\mathrm{OPC}$ 콘크리트에 비해 $f_{c k}$ 가 $20 \mathrm{MPa}$ 일 때 약 $40 \%$ 감소하 며, $f_{c k}$ 가 $100 \mathrm{MPa}$ 일 때 약 $50 \%$ 감소하였다. 한편, 플라이 애쉬나 실리카 품을 치환한 콘크리트의 $C_{i}$ 값은 $\mathrm{OPC}$ 콘 크리트에 비해 낮았는데, 그 저감율은 약 $12 \%$ 이내였다.

\section{$3.3 \mathrm{CO}_{2}$ 지수 $\left(C_{i}\right)$ 에 대한 혼화재 치환율의 영향}

일반강도 $\left(f_{c k}=23 \sim 30 \mathrm{MPa}\right)$ 및 고강도 $\left(f_{c k}=60 \sim 70 \mathrm{MPa}\right)$ 콘크리트 범주에서 각 혼화재의 치환율이 $C_{i}$ 값에 미치는 영향을 Fig. 7에 나타내었다. 일반적으로 혼화재의 치환 율이 증가할수록 콘크리트의 $C_{i}$ 값은 감소하였는데, 실험 결과들의 추세선으로부터 결정된 그 감소기울기는 콘크 리트 강도에 의한 영향이 매우 미미하였다. 또한 추세선 의 감소기울기는 혼화재 치환율이 약 $30 \%$ 이상에서 다소 


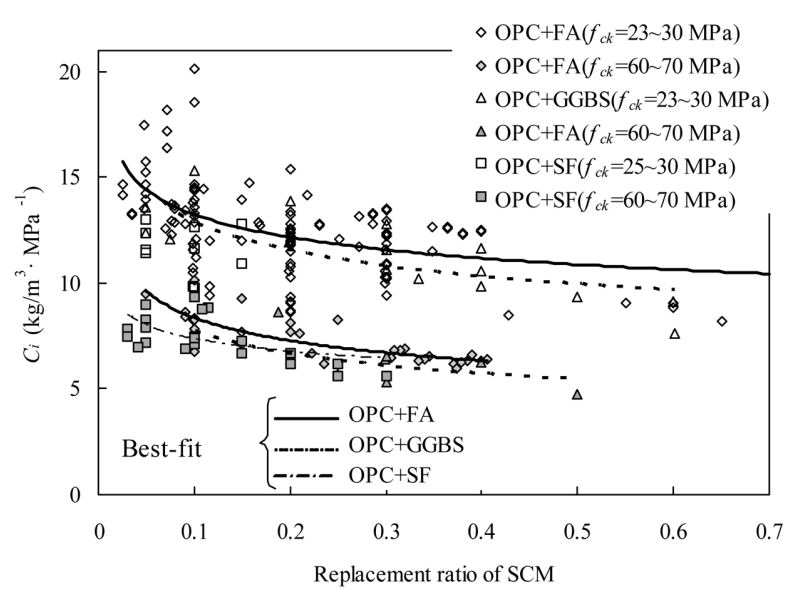

Fig. 7 Effect of replacement level of SCM on $C_{i}$

완만하여지는데, 이는 혼화재 치환율이 증가할수록 단위 시멘트 양의 증가와 함께 콘크리트 $\mathrm{CO}_{2}$ 배출량 저감율 이 다소 둔화됨을 의미한다. 동일 혼화재 치환율에서는 $\mathrm{OPC}+\mathrm{FA}$ 콘크리트가 $\mathrm{OPC}+\mathrm{GGBS}$ 콘크리트에 비해 높은 $C_{i}$ 값을 보였으며, 치환율이 $25 \%$ 이하일 때 $\mathrm{OPC}+\mathrm{SF}$ 콘 크리트의 $C_{i}$ 값이 가장 낮은 경향을 보였다. 따라서 $\mathrm{OPC}$ 콘크리트의 $\mathrm{CO}_{2}$ 저감을 위해서는 혼화재로서 $\mathrm{FA}$ 보다는 $\mathrm{GGBS}$ 와 $\mathrm{SF}$ 가 더 효율적이라고 판단된다.

\section{4 결합재 지수 $\left(B_{i}\right)$ 와 $\mathrm{CO}_{2}$ 지수 $\left(C_{i}\right)$ 의 관계}

$\mathrm{OPC}$ 콘크리트의 $\mathrm{CO}_{2}$ 배출량은 콘크리트 압축강도 및 이에 따른 단위 결합재 양과 혼화재 치환율에 의해 영 향을 받았다. 이를 고려하여 콘크리트의 $\mathrm{CO}_{2}$ 지수를 간 단하게 예측하기 위한 모델에서 결합재 지수 및 각 혼 화재의 치환율의 영향을 주요 변수로 비선형 회귀분석을 수행하였다. 혼화재가 치환되지 않았을 경우에는 단순히 $C_{i}$ 에 대한 $B_{i}$ 만의 영향을 고려하였으며, 각 혼화재 치환 율의 영향은 Fig. 7 의 분석 결과를 참고로 개별적으로 적 용하였다. 또한 결합재가 0 이면 $\mathrm{CO}_{2}$ 발생양도 0 이다. 이 와 같은 경계조건을 고려하여 $C_{i}$ 와 $B_{i}$ 의 관계는 다음 식 과 같이 모델링하였다.

$$
C_{i}=A_{1}\left[1-\left(R_{F}^{B_{1}}+R_{G}^{C_{1}}+R_{S}^{D_{1}}\right)\right] B_{i}
$$

여기서, $R_{F}, R_{G} R_{S}$ 는 각각 $\mathrm{FA}, \mathrm{GGBS}$ 및 $\mathrm{SF}$ 의 치환비이 다. 식 (6)에서 $A_{1}, B_{1}, C_{1}$ 및 $D_{1}$ 은 실험상수로서 실험 결 과의 회귀분석으로부터 각각 $1.1,1.15,1.1$ 및 0.95 로 결 정될 수 있었다(Fig. 8). 결국, 식 (4)와 (5)에 나타낸 $B_{i}$ 와 $C_{i}$ 의 정의로부터 콘크리트의 단위용적 $\left(1 \mathrm{~m}^{3}\right)$ 당 $\mathrm{CO}_{2}$ 배출 량 $\left(C_{d}\right)$ 은 다음 식 (7)에 의해 간편하게 평가될 수 있다.

$$
C_{d}=1.1\left[1-\left(R_{F}^{1.15}+R_{G}^{1.1}+R_{S}^{0.95}\right)\right] B\left(\mathrm{CO}_{2}-\mathrm{kg} / \mathrm{m}^{3}\right)
$$

혼화재가 치환되지 않은 콘크리트의 $\mathrm{CO}_{2}$ 배출량은 단
순히 $1.1 B$ 에 의해 산정될 수 있으므로, (7)에서 $\left(R_{F}^{1.15}+\right.$ $\left.R_{G}^{1.1}+R_{S}^{0.95}\right)$ 는 $\mathrm{OPC}$ 콘크리트에서 결합재 양이 동일할 때 혼화재의 치환에 따른 $\mathrm{CO}_{2}$ 감소율을 나타낸다.

\section{5 단위 결합재 양 $(B)$ 의 결정}

Fig. 4에 나타내었듯이 콘크리트의 단위 결합재 양은 압축강도에 반비례(OPC 콘크리트의 경우 -0.57승)하며, 동일 압축강도에서는 혼화재의 첨가에 의해 영향을 받는 다. 즉, 동일 압축강도의 $\mathrm{OPC}$ 콘크리트 단위 결합재 양 에 비해 $\mathrm{OPC}+\mathrm{FA}$ 콘크리트는 $1.05 \sim 1.16$ 배 많은 양을, $\mathrm{OPC}+\mathrm{GGBS}$ 콘크리트는 $0.98 \sim 1.03$ 배로서 상당히 비슷한 양을, $\mathrm{OPC}+\mathrm{SF}$ 콘크리트에서는 $0.79 \sim 0.94$ 배로서 낮은 경 향을 보였다. 식 (6)에서와 같이 각 혼화재 치환율의 영 향을 개별적으로 적용하면 압축강도 $($ 단위 $=\mathrm{MPa})$ 와 혼화 재 치환율의 영향을 고려한 $B_{i}$ 는 다음과 같이 선형적으 로 모델링될 수 있다.

$$
B_{i}=A_{2}\left(f_{c k}\right)^{P_{1}}\left[1+\left(R_{F}^{B_{2}}+R_{G}^{C_{2}}-R_{S}^{D_{2}}\right)\right]
$$

여기서, 실험상수인 $A_{2}, P_{1}, B_{2}, C_{2}$ 및 $D_{2}$ 는 Fig. 9에 나 타낸 바와 같이 실험 결과들의 회귀분석으로부터 각각 82 , $-0.55,1.7,3.0,3.0$ 으로 각각 결정될 수 있었다. Fig. 9에 나타낸 추세선과 실험 결과의 상관계수 $\left(R^{2}\right)$ 가 Fig. 8 에 비 해 다소 낮은 이유는 콘크리트의 배합설계 시 단위 결합 재 양(또는 단위 수량)을 주로 연구자의 경험에 의해 결 정하기 때문이다. 하지만 식 (8)로부터 소요 압축강도에 대한 $B_{i}$ 를 비교적 단순하게 예측할 수 있으며, 식 (4)를 적용하면 콘크리트 단위 결합재 양 $(B)$ 을 혼화재 치환율을 고려하면서 다음과 같이 결정할 수 있다.

$$
B=82\left(f_{c k}\right)^{0.45}\left[1+\left(R_{F}^{1.7}+R_{G}^{3}-R_{S}^{3}\right)\right]\left(\mathrm{kg} / \mathrm{m}^{3}\right)
$$

\section{4. 콘크리트 $\mathrm{CO}_{2}$ 저감을 위한 혼화재 설계}

콘크리트의 $\mathrm{CO}_{2}$ 배출량에 대해 $\mathrm{OPC}$ 재료가 차지하는

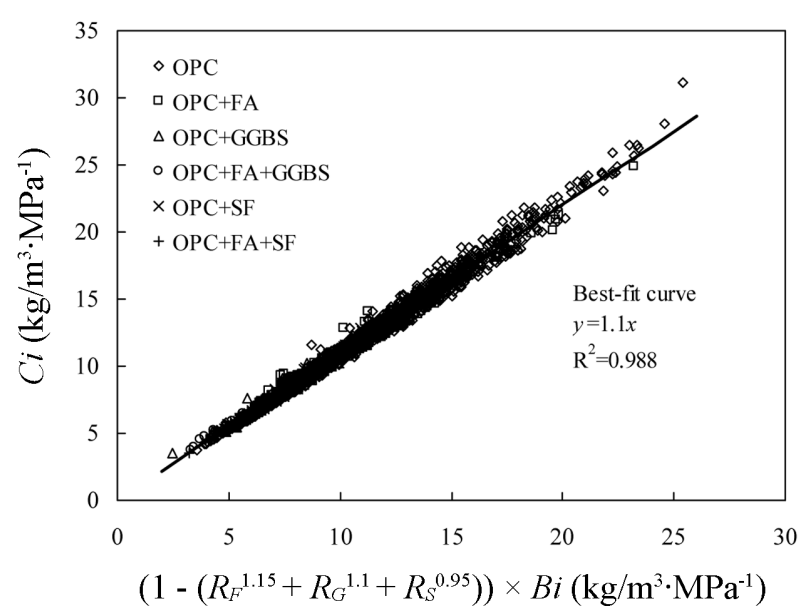

Fig. 8 Regression analysis for relationship between $C_{i}$ and $B_{i}$ 


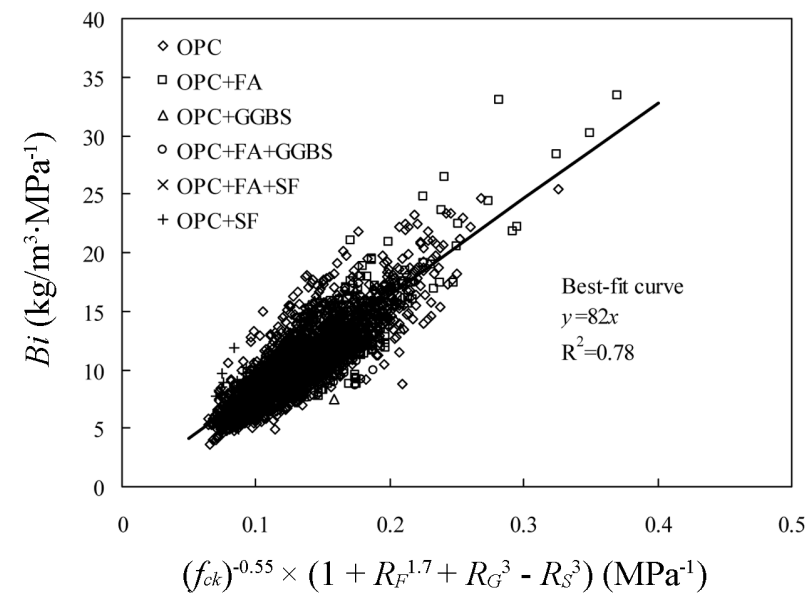

Fig. 9 Regression analysis for determination of $B_{i}$

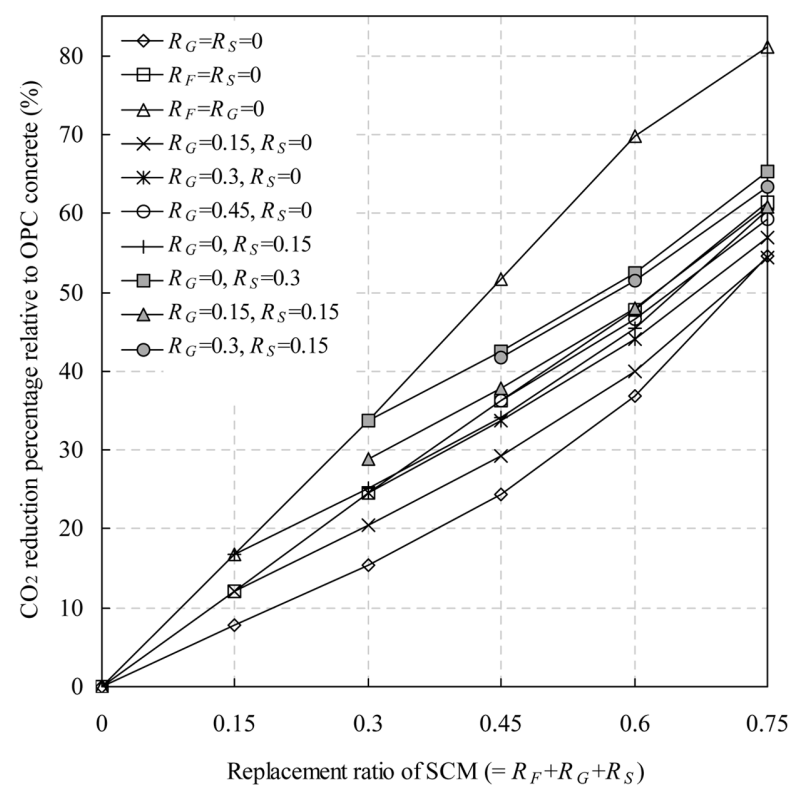

(a) Combination of different SCMs

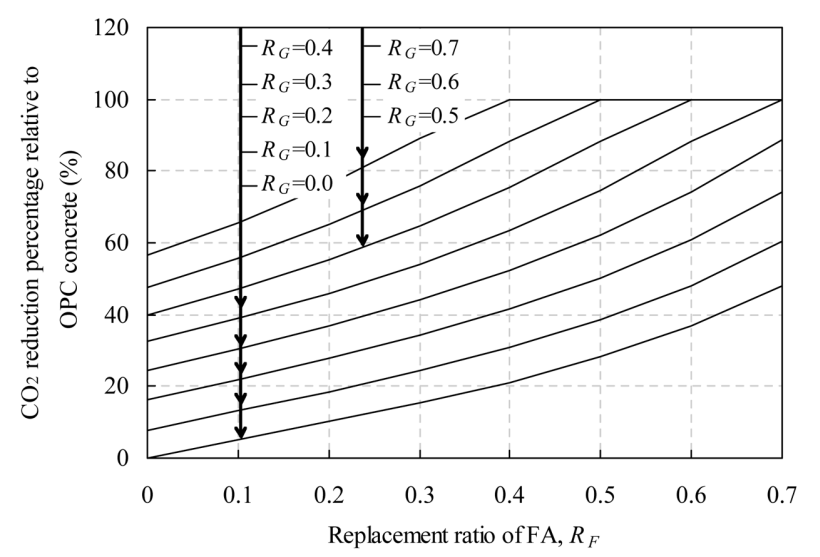

(b) Combination of FA and GGBS

Fig. 10 Examples for SCM design chart $\left(f_{c k}=30 \mathrm{MPa}\right)$

비율은 $80 \%$ 가 넘는다. 따라서 목표 압축강도를 만족시 키면서 $\mathrm{CO}_{2}$ 저감을 위한 콘크리트 배합을 위해서는 적 절한 혼화재의 선택 및 치환율이 중요하다. 식 (9)에서 목 표강도에 대하여 혼화재와 치환율을 선택하여 단위 결합
재 양을 결정하고 이를 식 (7)에 대입하면 콘크리트에서 $\mathrm{CO}_{2}$ 배출량 및 혼화재 사용에 따른 $\mathrm{OPC}$ 콘크리트 대비 $\mathrm{CO}_{2}$ 저감율을 평가할 수 있다. 혼화재로서 $\mathrm{FA}, \mathrm{GGBS}$ 및 $\mathrm{SF}$ 의 치환율에 따른 콘크리트 $\mathrm{CO}_{2}$ 저감율을 Fig. 9에 나 타내었다. 플라이애쉬만을 이용하여 치환하였을 때가 $\mathrm{GGBS}$ 및 $\mathrm{SF}$ 의 치환에 비해 $\mathrm{CO}_{2}$ 저감율이 낮았으며, $\mathrm{SF}$ 만을 이용하여 치환하였을 때가 $\mathrm{CO}_{2}$ 저감에 가장 유리 하였다. Igcc(international green construction code) ${ }^{11}$ 에서 는 건축물에서 전과정 평가에 의한 $\mathrm{CO}_{2}$ 저감율을 동일 규모의 기준 건축물 대비 $20 \%$ 이상을 요구하고 있다. OPC 콘크리트 대비 $\mathrm{CO}_{2}$ 저감율을 $20 \%$ 이상 달성하기 위해 서는 FA만을 혼화재로 이용하는 경우 그 치환율은 약 $45 \%$ 이상, $15 \%$ 의 $\mathrm{GGBS}$ 를 함께 치환하는 경우의 $\mathrm{FA}$ 치 환율은 약 $15 \%$ 이상이 요구된다(Fig. 10(a)).

보통강도 콘크리트에서는 경제성 및 산업부산물 재활 용 측면에서 $\mathrm{SF}$ 보다는 $\mathrm{FA}$ 와 $\mathrm{GGBS}$ 가 주로 혼화재로 이 용된다. FA와 GGBS가 치환된 콘크리트에서 $\mathrm{OPC}$ 콘크 리트 대비 $\mathrm{CO}_{2}$ 저감율을 Fig. 10 (b)에 나타내었다. $\mathrm{OPC}$ 콘크리트 대비 $\mathrm{CO}_{2}$ 저감율을 $20 \%$ 이상 달성하기 위해서 는 GGBS $30 \%$ 이상, GGBS $20 \%$ 와 $\mathrm{FA} 10 \%$ 이상, 또는 $\mathrm{GGBS} 10 \%$ 와 $\mathrm{FA} 25 \%$ 이상의 치환이 요구된다. 이와 같 이 식 (7)과 (9) 또는 Fig. 10과 같은 설계차트를 이용하 여 콘크리트 배합에서 목표 압축강도 및 목표 $\mathrm{CO}_{2}$ 저감 율을 만족시키기 위한 단위 결합재 양과 함께 혼화재의 선택과 그 치환율을 간략히 결정할 수 있다.

\section{5. 결 론}

콘크리트 환경설계에 중요하게 이용될 수 있는 $\mathrm{CO}_{2}$ 저 감에 기반한 혼화재의 설계를 위하여 결합재 지수와 $\mathrm{CO}_{2}$ 지수 개념을 이용하였다. 3240 개의 실험 데이터들에 대 한 회귀분석으로부터 콘크리트의 결합재 지수와 $\mathrm{CO}_{2}$ 지 수의 평가식을 제시하였으며, 이를 이용하여 목표 압축 강도와 $\mathrm{CO}_{2}$ 저감율을 만족시킬 수 있는 단위 결합재 양 및 각 혼화재(플라이애쉬, 고로슬래그 및 실리카 품 등) 의 치환율을 비교적 간단하게 결정할 수 있다. 비록 제 안된 모델에서 콘크리트 $\mathrm{CO}_{2}$ 평가 시스템은 건축물의 사용연한 및 폐기를 고려하고 있지 않으며, 운반에 의한 $\mathrm{CO}_{2}$ 배출량도 콘크리트 공장 및 재료공급자 위치에 따 라 약간 변동이 있을 수 있다. 하지만 운반거리의 변동 에 의한 $\mathrm{CO}_{2}$ 배출량의 차이는 매우 미미하며, 콘크리트 $\mathrm{CO}_{2}$ 배출량의 $80 \%$ 이상이 시멘트에 기인하고 있다. 따 라서 $\mathrm{CO}_{2}$ 저감을 위한 콘크리트 혼화재 설계에 대한 이 제안모델은 연구 및 레미콘 공장 등의 실용적 측면에서 중요하게 이용될 수 있을 것으로 기대된다.

$\mathrm{CO}_{2}$ 저감 기반 콘크리트 배합설계를 위한 기초자료 분 석으로부터 다음과 같은 결론을 얻었다.

1) 결합재 지수는 혼화재의 치환에 관계없이 콘크리트 압축강도의 증가와 함께 감소하면서 $5 \mathrm{~kg} / \mathrm{m}^{3} \cdot \mathrm{MPa}^{-1}$ 에 수렴하는 경향을 보였다. 
2) $\mathrm{CO}_{2}$ 지수도 콘크리트 압축강도 증가와 함께 감소 하였다. 동일 혼화재 치환율에서는 플라이애쉬 치 환이 고로슬래그 치환보다 높은 $\mathrm{CO}_{2}$ 지수 값을 나 타내었다.

3) $\mathrm{CO}_{2}$ 지수와 결합재 지수는 각 혼화재들의 치환율 을 변수로 선형관계로서 모델링될 수 있었다. 또한 결합재 지수도 콘크리트 압축강도 및 각 혼화재들 의 치환율을 변수로 선형관계로 제시될 수 있었다.

4) 콘크리트의 $\mathrm{CO}_{2}$ 배출량 저감을 위한 혼화재로서 효 율성은 실리카 품, 고로슬래그, 플라이애쉬 순으로 나타났다. 시멘트 콘크리트 대비 $\mathrm{CO}_{2}$ 저감율을 $20 \%$ 이상 달성하기 위해서는 고로슬래그 $30 \%$ 이상, 고 로슬래그 $20 \%$ 와 플라이애쉬 $10 \%$ 이상, 또는 고로 슬래그 $10 \%$ 와 플라이애쉬 $25 \%$ 이상의 치환이 요 구되었다.

\section{감사의 글}

이 논문은 국토해양부 R\&D정책인프라사업의 연구비 지원(과제번호: 11 기술표준화10-1)에 의해 수행되었습니다.

\section{참고문헌}

1. Korea Concrete Institute, Concrete and Environment, Kimoondang Publishing Co., Seoul, 2011, pp. 1-15.

2. Korea Concrete Institute, Concrete and Environment, Kimoondang Publishing Co., Seoul, 2011, pp. 16-30.
3. Ali, M. B., Saidur, R., and Hossain, M., S., "A Review on Emission Analysis in Cement Industries," Renewable and Sustainable Energy Reviews, Vol. 15, No. 5, 2011, pp. 22522261.

4. Gartner, E., "Industrially Interesting Approaches to 'Low$\mathrm{CO}_{2}$ ' Cements," Cement and Concrete Research, Vol. 34, No. 9, 2004, pp. 1489-1498.

5. Korea LCI Database Information Network, http://www.edp. or.kr/lcidb.

6. Damineli, B. L., Kemeid, F. M., Aguiar, P. S., and John, V. M., "Measuring the Eco-Efficiency of Cement Use," Cement and Concrete Composites, Vol. 32, No. 8, 2010, pp. 555562.

7. ISO, Environmental Management-Life Cycle AssessmentPrinciples and Framework, ISO 14040, International Standardisation Organisation (ISO), 2006.

8. Kim, T. H. and Tae, S. H., "A Study on the Development of an Evaluation System of $\mathrm{CO}_{2}$ Emission in the Production of Concrete," Journal of the Korea Concrete Institute, Vol. 22, No. 6, 2010, pp. 787-796.

9. Sakai, K. and Kawai, K., "JSCE Guidelines for Concrete No. 7: Recommendation of Environmental Performance Verification for Concrete Structures," Japan Society of Civil Engineering, 2006, 29 pp.

10. CEN, European Committee for Standardization, NF EN 1971. Cement-Part 1: Composition, Specifications and Conformity Criteria for Common Cements, 2001.

11. IGCC Public Comment Hearing Committee, International Green Construction Code, International Code Council, INC., USA, 2010.

요 약 이 연구에서는 2464 개의 시멘트 콘크리트 배합과 776 개의 혼화재가 치환된 혼합 시멘트 콘크리트 배합을 포 함하는 실험 데이터베이스를 이용하여 콘크리트 압축강도 및 혼화재 치환율에 따른 콘크리트 $\mathrm{CO}_{2}$ 배출량을 평가하였 다. 국내 생애주기 데이터 목록에 기반한 콘크리트 $\mathrm{CO}_{2}$ 평가에서 고려된 시스템은 요람에서 현장 콘크리트 타설 전까 지로서 구성재료, 운반 및 생산단계를 포함하고 있다. 콘크리트의 성능 효율성 지표로서 결합재 지수와 $\mathrm{CO}_{2}$ 지수가 분 석되었으며, 콘크리트 $\mathrm{CO}_{2}$ 배출량을 평가하기 위한 단순 식이 각 혼화재의 치환비 및 콘크리트 압축강도의 함수로서 제시되었다. 따라서 이 제안된 모델은 목표 압축강도 및 목표 시멘트 콘크리트 대비 $\mathrm{CO}_{2}$ 배출 저감율을 만족하는 콘크 리트 배합설계를 위하여 단위 결합재 양 및 혼화재 종류와 치환비를 결정하는 데 가이드 라인으로서 유용하게 이용될 수 있을 것으로 기대된다.

핵심용어 : $\mathrm{CO}_{2}$, 혼화재, 단위 결합재 양, 압축강도 